\title{
Preservation of keratinized gingiva around dental implants using a diode laser when uncovering implants for second stage surgery
}

\section{Purpose}

The aim of the present study was to assess if a 940-nm diode laser or a traditional scalpel approach is more effective in minimizing patient comfort and postoperative sequelae, preserving peri-implant keratinized mucosa, and in enhancing impression quality after uncovering dental implants.

\section{Materials and methods}

We designed a prospective, split mouth, single blinded, randomi-zed controlled trial with patients who needed uncovering of dental implants. Our analysis included 388 implants in 73 patients. Split mouth technique was used to compare two approaches for uncovering implants: laser study group vs. scalpel control group. Patients were evaluated for intra- and post-operative pain and bleeding. At 1, 2, and 3 weeks post procedure patients in both groups were rechecked for postoperative sequelae, keratinized mucosal thickness quality and quantity, and accuracy of the implant emergence profile.

\section{Results}

The laser study group showed that there was a reduction in postoperative pain and bleeding that was statistically significant in comparison to the control group. There were also statistically significant differences in gingival color and presence or absence of soft tissue edema and in the gingival was emergency profile between the laser and scalpel sides at 1, 2, and 3 weeks' post-procedure. Statistically significant differences $(p<0.001)$ were observed between the two groups in the criteria of ideal or satisfactory soft tissue projection in the gingival emergency profile, which indicates that impressions can be taken immediately or within 1 week after laser surgery.

\section{Conclusion}

Uncovering dental implants using a diode laser operating at the wavelength of $940 \pm 10 \mathrm{~nm}$, and a power output of $0.4-10 \mathrm{~W}$ is recommended for preparing an accurate implant emergence profile. Laser treatment can also effectively preserve keratinized mucosa around implants in comparison to the conventional scalpel technique.

Keywords: Dental implants; diode laser; emergence profile; scalpel approach, keratinized gingiva

\section{Introduction}

Appropriate dental implant planning and treatment should consider factors for long-term success, including appropriate implant dimensions (vertical, sagittal and transverse), bone quality, healthy soft tissues around the implant shoulder, and non-mobile keratinized gingiva (1). In consideration of these factors, modern approaches in the field of dentistry include performing more conservative surgical procedures, reducing the length of rehabilitation time, and promoting quicker osseointegration. Furthermore, scientific interest in the field of postoperative care has

\author{
Ra'ed Mohammed Ayoub \\ Al-Delayme ${ }^{1,2,3}$ (i)
}

ORCID IDs of the authors: R.M.A.A.D. 0000-0001-8989-2807

'Eastman Institute for Oral Health, University of Rochester, School of Medicine and Dentistry, New York, USA

${ }^{2}$ Faculty of Dentistry, Dijlah University College, Baghdad, Iraq

${ }^{3}$ Oral and Maxillofacial Dept., Alyarmouk Teaching Hospital, Baghdad, Iraq

Corresponding Author: Ra'ed Mohammed Ayoub Al-Delayme

E-mail: raedmaxfax@gmail.com Received: 24 September 2018 Revised: 1 January 2019 Accepted: 3 May 2019

DOI: 10.26650/eor.20190022 
intensified in terms of tissues healing more rapidly and patient compliance improving (2).

Different techniques can be used for second stage implant surgery, such as uncovering the implant with either a scalpel, tissue punch, or laser (3). Identification of a patient's periodontal biotype is fundamental to optimal planning of therapeutic management in implantology (4). The sufficiency of the attached gingiva (AG) around fixed restorations is the key factor in choosing a technique for uncovering implants (5). When the attached gingiva around implants is sufficiently thick, the implants can be uncovered without subepithelial connective tissue grafts (SCTG) or free gingival grafts (FGG) (6-8).

The laser technique has comparable results to the traditional scalpel technique, but with less time, micro-invasiveness, and improved patient compliance $(3,9)$. Furthermore, there is a reduced emotional effect with laser treatment, since laserassisted surgery is not considered a particularly invasive surgery (9). Using lasers also decreases intra-operative bleeding, therefore the use of anesthetic and vasoconstrictor agents can be reduced (2). Additionally, secondary infections can be avoided postoperatively as lasers have antiseptic properties. The bio-modulating property of lasers further improves the healing process (10-13). Many clinical trials have confirmed that diode lasers reduce pain during surgery and ensure better wound healing, less swelling, edema and scarring, and better coagulation (14-16).

Soft tissue vaporization with the use of diode lasers has been widely described in the literature (17). Lasers play a significant role in soft tissue vaporization and in the decontamination of infected implant surfaces (18). However, there is a risk that the bone can be overheated bone on application of these devices during the surgery (19). The risk of thermal injuries to the bone are relatively high due to the direct bone-implant contact. In the implant neck area there is a particular composition of soft tissue where blood flow is reduced, allowing for a higher risk of thermal injury to the bone via the implant. Eriksson et al. $(20,21)$ found in several studies, permanent changes were made to the bone structure by increasing the temperature of bone tissue by $10^{\circ} \mathrm{C}$ for $60 \mathrm{~s}$. It can only be assumed therefore, that the ideal and safe tissue temperature gradient $(\Delta \mathrm{Ta})$ should be below $10^{\circ} \mathrm{C}$.

Here we performed a clinical trial to test our hypothesis that patient comfort would improve with $940 \mathrm{~nm}$ diode laser compared to the traditional scalpel approach for uncovering dental implants. The aim of this study was to perform a prospective, split mouth clinical analysis to determine if a $940-\mathrm{nm}$ diode laser is more effective at preserving the keratinized mucosa surrounding an implant compared to the traditional scalpel approach. The null hypothesis tested in this research is that no difference can be observed between the two protocols.

\section{Materials and Methods}

\section{Study design}

In this prospective, split mouth, single blinded, randomi $\neg$ zed controlled trial, the study sample was composed of patients presenting to the Iraqi specialized dental implant and cosmetics center in Baghdad, Iraq, from April 2014 to May 2015. The required approval for the study was obtained from the Laser Institute Committee, and we followed the Declaration of Helsinki guidelines. A total of 73 patients, 47 (64.38\%) men and 25 (34.24\%) women, aged 18 - 68 years (mean $31.62 \pm 14.76$ years) at the time of operation were enrolled in the study and received a total of 388 implants (taper, external hexagon connection; BioHorizons, LaserLok, USA). Patients underwent at least more than one dental implant in the left and right mandibular or maxillary regions and sufficient dimensions of keratinized mucosa around the implants, and $56(76,71 \%)$ patients had a history of partial edentulism, 9 (12.32\%) had complete edentulism in the upper or lower jaws, and 6 (8.21\%) had either a full upper or a lower edentulous jaw. The procedure was explained, and informed consent was obtained from all patients. As this study used a "split-mouth method", one site was assigned for uncovering dental implant using a $940 \mathrm{~nm}$ diode laser (study group) and the contralateral site was assigned for uncovering the dental implant using the ordinary surgical scalpel method (control group). The study and control sites were assigned in the same patient to avoid bias from individual variations. Patients were sequentially numbered from 1 to 73 . The treatment modality (laser exposure vs scalpel exposure) and the operating site (right vs. left) were determined by tossing a coin, where 'face' was the test site and 'back' was the control site. The treatment modality (laser exposure vs scalpel exposure) sequence was randomly assigned. The laser exposure study group consisted of 194 dental implants; the scalpel exposure control group consisted of 194 dental implants.

Patients were examined and evaluated clinically and radiographically. All patients had osseointegrated dental implants. Preoperative medications were not prescribed in any of the cases. Exclusion criteria were: severe systematic diseases, uncompensated diabetes, or uncontrolled periodontal disease, smoking more than 10 cigarettes daily, failed dental implant, inflammation or peri-implant inflammation, failed examination appointments, radiolucent line around the dental implant, exposed dental implant, and parafunctional habits that could impact osseointegration. All patients had good oral hygiene and sufficient bone volume to allow dental implant insertion. Inclusion criteria were: delayed loading dental implant, delayed insertion dental implant, two stage protocol of dental implant, and healthy keratinized gingival tissues. At the examination appointments, all patients had panoramic radiographs taken. Demographic and clinical data, for example, patient age, gender, clinical presentation, past surgical history, and medical history were noted. This study includes the following parameters: 1) gingival health, 2) mucosal thickness determined using a periodontal probe with a rubber stopper, 3) oral hygiene, 4) bone quality, and 5) the duration of surgical operation of each group. Regarding bone quality, all implant sites were classified as bone type II (implant bone site with a thick layer of compact bone surrounding a core of dense trabecular bone) or bone type III (implant bone site with a thin layer of compact bone surrounding a core of dense trabecular bone) according to Lekholm and Zarb (22).

\section{Surgical procedures}

Patients were treated with dental implants that were at least $12 \mathrm{~mm}$ in length. All implants were placed by the same 
operator (RA) according to the manufacturer's protocol using labially or buccally based flaps. All of the surgeries were carried out without intercurrences, and post-operative follow up was favorable for all patients. All 73 patients were radiographed immediately after surgery and at 3 months and 6 months' follow-up. After osseointegration, the second stage surgery was performed for each patient and the environmental preparations in both groups were the same.

In the scalpel group (control), 194 dental implants were exposed using the scalpel to create a circular incision smaller than the size of the dental implant and using topical application of $20 \%$ benzocaine; if pain was greater than 45 $\mathrm{mm}$ according to VAS, anesthesia should be administered. After a 3-week interval the contralateral implant was uncovered using the laser (study group). The 3-week interval was scheduled to evade postoperative outcome parameters of one procedure influencing the other.

In the experimental (laser) group, 194 implants were uncovered by using the $940 \mathrm{~nm}$ laser diode after tip initiation to make a small opening. This opening was widened until the cover was completely exposed. Subsequently, the tissue over the implant was ablated until the opening allowed for the removal of the screw. A diode laser (commercial trade mark epic Biolase, Irvine, CA, USA) was used, emitting a wavelength of $940 \pm 10 \mathrm{~nm}$, and a power output of 0.4-10 W in a pulse duration of 100 microseconds, and a pulse interval of 200 microseconds, with a duty cycle of $33 \%$. The optic fiber was $300 \mu \mathrm{m}$ with a length of $9 \mathrm{~mm}$, average power $0.9 \mathrm{~W}$, and a continuous emission CP1 (Comfort Pulse) mode. The aiming beam was a visible laser diode, max $1 \mathrm{~mW}, 625$ - $670 \mathrm{~nm}$, continuous or intermittent. Laser opening of the implant was conducted without any kind of anesthesia. If pain was greater than $45 \mathrm{~mm}$ according to VAS, anesthesia was administered. The cover screw was unscrewed, and the gingival healing abutment was placed inside the implant according to the size and shape of the implant used, in both groups.

\section{Clinical parameters}

We used a single qualified experienced blinded operator to compare the parameters of both techniques. He was not involved in the surgeries themselves. Each assessment was repeated three times. The mucosal thickness was determined by the depth of penetration of the probe from the external surface of the mucosa to the point where bony resistance could be felt. The stopper was then adjusted, and the depth of penetration/thickness was measured in millimeters on a geometric scale/ruler. The measurements were done at three points on the crest of the edentulous ridge, namely mesial, mid and distal mucosa in the buccal site. All patients in both groups were assessed at baseline (before uncovering the implant) and then postoperatively at 1, 2, and 3 weeks. The duration of surgery was counted in minutes. The need for local anesthesia was determined and if the pain was greater than $54 \mathrm{~mm}$ (mild pain), anesthesia was administered. Intraand post-operative bleeding were determined by the World Health Organization (WHO) bleeding scale (23) which defined it as: grade 0: no bleeding, grade 1: petechial bleeding, grade 2: mild blood loss (clinically significant), grade 3: gross blood loss, requires transfusion, grade 4: debilitating blood loss, retinal, or cerebral associated with fatality.
In the follow up period, gingival bleeding was postoperatively evaluated at 1, 2, and 3 weeks by visual bleeding from the emergency profile noticed by opening of the gingival former defined as bleeding during probing (using periodontal probe), according to the following modified criteria (modified by the author):grade 0:no bleeding grade 1:one bleeding point, grade 2 :several isolated bleeding points or a small blood area, grade 3:cavity filled with blood soon after probing, grade 4: profuse bleeding when probing, blood spread outside the cavity.

The pain level was evaluated using a 170-mm Heft-Parker visual analog scale (VAS; Figure 1). Each pa $\neg$ tient had the VAS explained to them. The VAS was divided into 4 categories: 1) no pain corresponded to $0 \mathrm{~mm}$; 2) mild pain was defined as greater than $0 \mathrm{~mm}$ and less than or equal to $54 \mathrm{~mm}$ and included the descriptors of faint, weak, and mild pain; 3) moderate pain was defined as greater than $54 \mathrm{~mm}$ and less than $114 \mathrm{~mm}$; and 4) severe pain was defined as equal to or greater than $114 \mathrm{~mm}$ and in $\neg$ cluded the descriptors of strong, intense, and maximum.

Place a mark on the line blow to show the amount of pain that you feel

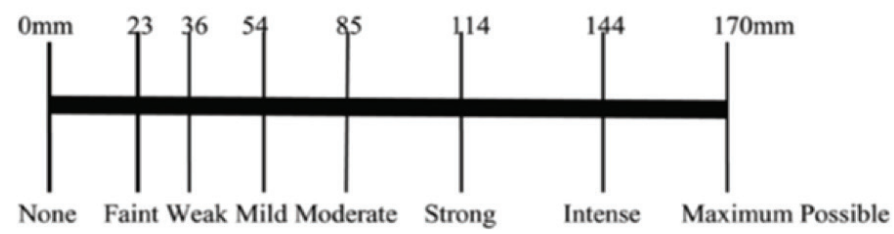

Figure 1. Heft-Parker visual analog scale (VAS) used for the pain assessment. The millimeter demarcations are not shown on the patient's VAS.

In the post-operative follow-up, the emergency profile was evaluated by gingival color and the presence or absence of edematous soft tissue and the need to correct this. Gingival color was evaluated using the following modified gingival index (modified by the author): grade 0: normal gingiva color, grade 1: slight change in color, slight edema, grade 2: moderate redness and glazing, grade 3: marked redness. The time for impression taking was determined if there was an ideal or satisfactory soft tissue projection of the gingival emergency profile. If inadequate projection of the soft tissue was observed, impression were delayed until there was evidence of satisfactory projections.

\section{Statistical analysis}

Statistical analysis was performed using SPSS13.0 (Statistical Package for Social Sciences, Chicago, IL, USA). The paired t test was used to analyze variables predicting changes between the both groups. The categorical variables were compared with either the Chi-square or Fisher's exact tests. The confidence interval was set to $95 \%$ and $p<0.05$ was considered statistically significant.

\section{Results}

In this study, the mean follow-up period was three weeks after uncovering the dental implant. Neither serious complications nor complaints were reported after surgery. None of the patients showed any adverse reactions to laser 
treatment. All 73 patients completed the follow-up visits, and therefore a total of 388 implants were analyzed in this study.

There were no significant differences in soft tissue thickness on the mesial, mid and distal sites upon uncovering the implant in the scalpel and laser groups (Table 1) at the time of uncovering the dental implant. However, there was statistically significant difference at 1, 2, and 3 weeks after uncovering the dental implant, as shown in Tables 2, 3 and 4.
The average duration of surgery was $1.14 \pm 1.30$ minutes in the scalpel group versus $2.35 \pm 0.97$ minutes in the laser group $(p<0.05)$. (Table 1). There was significantly less postoperative pain, which led to a decreased need for local anesthesia, in the laser group ( 2 cases only) compared to the scalpel group (58 cases). In the scalpel group, the mean pain value during uncovering the dental implant was $78.42 \pm 11.62 \mathrm{~mm}$ (Table 1). In the laser group, the mean pain value was 31.66 \pm 9.74 . No severe pain was reported in either group during

Table 1. The operative assessment in both groups $\left({ }^{*} p<0.05 ; t p<0.01 ; \neq p<0.001 ;\right.$ VAS: visual analogue scale, SD: standard deviation).

\begin{tabular}{|c|c|c|c|}
\hline Criteria & Scalpel group & Laser group & p value \\
\hline \multicolumn{4}{|c|}{ Mucosal thicknesses at the time of uncovering the dental implant ( $\mathrm{mm}$ ) } \\
\hline Mesial mucosa & $1.64 \pm 0.47$ & $1.72 \pm 0.39$ & 0.81 \\
\hline Mid mucosa & $1.23 \pm 0.56$ & $1.20 \pm .61$ & 0.73 \\
\hline Distal mucosa & $1.57 \pm 0.73$ & $1.66 \pm 0.69$ & 0.91 \\
\hline Mean of surgical duration procedure in (min) & $1.14 \pm 1.30$ & $2.35 \pm 0.97$ & $0.012^{*}$ \\
\hline Cases Need for infiltration local anesthesia & $58(29.82 \%)$ & $2(2.73 \%)$ & $0.001+$ \\
\hline \multicolumn{4}{|l|}{ Intra and post-operative bleeding } \\
\hline Grade 0 & $00(00)$ & $181(93.2)$ & $0.000 \neq$ \\
\hline Grade1 & $28(14,43)$ & $13(6,70)$ & $0.017^{*}$ \\
\hline Grade 2 & $166(85.56)$ & $00(000)$ & $0.000 \neq$ \\
\hline \multicolumn{4}{|l|}{ Pain (VAS) } \\
\hline No pain & $00(00)$ & $19(26.02)$ & $0.000 \neq$ \\
\hline Weak & $15(20.54)$ & $52(71.23)$ & $0.001 \dagger$ \\
\hline Moderate & $58(79.45)$ & $2(2.73)$ & $0.000 \neq$ \\
\hline Sever & $00(00)$ & $00(00)$ & NA \\
\hline Mean VAS values (mm) & $78.42 \pm 11.62$ & $31.66 \pm 9.74$ & $0.000 \neq$ \\
\hline
\end{tabular}

Table 2. Postoperative assessment at 1 week in both groups ( ${ }^{*} p<0.05 ; t p<0.01 ; \neq p 0.001 ; S D$ :standard deviation).

\begin{tabular}{|c|c|c|c|c|}
\hline Variable & Index & Scalpel group & Laser group & $\mathbf{p}$ \\
\hline \multirow[t]{3}{*}{ Mucosal thicknesses (mm) } & Mesial mucosa & $1.93 \pm 0.62$ & $1.77 \pm 0.36$ & $0.000 \neq$ \\
\hline & Mid mucosa & $1.59 \pm 0.77$ & $1.30 \pm .68$ & $0.001 \dagger$ \\
\hline & Distal mucosa & $1.84 \pm 0.90$ & $1.69 \pm 0.53$ & $0.007 \dagger$ \\
\hline \multirow[t]{7}{*}{ Bleeding } & Visual bleeding & 19(9.79) & $00(00)$ & $0.000 \neq$ \\
\hline & Bleeding on probing & & & \\
\hline & Grade 0 & $00(00)$ & $140(72.16)$ & $0.000 \neq$ \\
\hline & Grade 1 & $00(00)$ & $31(15.97)$ & $0.000 \neq$ \\
\hline & Grade 2 & 19(9.79) & $17(8.76)$ & $0.000 \neq$ \\
\hline & Grade 3 & 147(75.77) & $06(3.09)$ & $0.000 \neq$ \\
\hline & Grade 4 & $28(14.43)$ & $00(00)$ & $0.000 \neq$ \\
\hline \multirow{4}{*}{$\begin{array}{l}\text { Gingival color (modified Gingival } \\
\text { index) }\end{array}$} & Grade 0 & $00(00)$ & $113(58.24)$ & $0.000 \neq$ \\
\hline & Grade 1 & $30(15.46)$ & $63(32.47)$ & $0.004 \dagger$ \\
\hline & Grade 2 & $99(51.03)$ & $18(9.27)$ & $0.000 \neq$ \\
\hline & Grade 3 & $65(33.5)$ & $00(00)$ & $0.000 \neq$ \\
\hline \multirow{2}{*}{$\begin{array}{l}\text { Soft tissue edema in the gingival } \\
\text { emergency profile }\end{array}$} & Present & $147(75.77)$ & $38(19.58)$ & $0.000 \neq$ \\
\hline & Absence & $47(24.22)$ & $156(80.41)$ & \\
\hline \multirow[t]{2}{*}{ Secondary correction } & Need & NA & NA & NA \\
\hline & No need & NA & NA & \\
\hline \multirow[t]{2}{*}{ Time for impression taking } & Ideal or satisfactory soft tissue projection & $00(00)$ & $166(85.56)$ & $0.000 \neq$ \\
\hline & Inadequate projection of the soft tissue & $194(100)$ & $28(14.43)$ & $0.000 \ddagger$ \\
\hline
\end{tabular}


the procedure. Neither group experienced any postoperative pain at 1,2, and 3 weeks.

Intra- and post-operative bleeding was significantly different in the laser group compared to the scalpel group. No patient in the laser group experienced Grade 2 WHO bleeding; no patient in either group experienced Grade 3 or 4 WHO bleeding (Table 1). We also found a significant difference in postoperative gingival bleeding $(p<0.001)$ at 1 , 2 , and 3 weeks, as shown in Tables 2, 3 and 4.

We further observed significant postoperative differences

Table 3. Postoperative assessment at 2 weeks in both groups ( ${ }^{*} p<0.05 ; \neq p<0.01 ; \neq p<0.001 ; S D$, standard deviation).

\begin{tabular}{|c|c|c|c|c|}
\hline Criteria & Index & Scalpel group & Laser group & $\mathbf{p}$ \\
\hline \multirow[t]{3}{*}{ Mucosal thicknesses (mm) } & Mesial mucosa & $1.76 \pm 0.53$ & $1.72 \pm 0.39$ & $0.000 \neq$ \\
\hline & Mid mucosa & $1.48 \pm 0.49$ & $1.20 \pm .61$ & $0.000 \neq$ \\
\hline & Distal mucosa & $1.69 \pm 0.77$ & $1.66 \pm 0.69$ & $0.000 \neq$ \\
\hline \multirow[t]{7}{*}{ Bleeding } & Visual bleeding & $00(00)$ & $00(00)$ & NA \\
\hline & Bleeding on probing & & & \\
\hline & Grade 0 & $43(22.16)$ & $186(95.87)$ & $0.000 \neq$ \\
\hline & Grade 1 & $121(62.37)$ & $08(4.12)$ & $0.000 \neq$ \\
\hline & Grade 2 & $14(7.21)$ & $00(00)$ & $0.000 \neq$ \\
\hline & Grade 3 & $10(0.51)$ & $00(00)$ & $0.000 \neq$ \\
\hline & Grade 4 & $6(3.09)$ & $00(00)$ & $0.000 \neq$ \\
\hline \multirow{4}{*}{$\begin{array}{l}\text { Gingival color } \\
\text { Modified Gingival index }\end{array}$} & Grade 0 & $86(44.32)$ & 177(91.23) & $0.001+$ \\
\hline & Grade 1 & $29(14.94)$ & $14(7.21)$ & $0.001+$ \\
\hline & Grade 2 & $48(24.74)$ & $3(1.54)$ & $0.000 \neq$ \\
\hline & Grade 3 & $31(15.97)$ & $00(00)$ & $0.000 \neq$ \\
\hline \multirow{2}{*}{$\begin{array}{l}\text { Soft tissue edema in the gingival } \\
\text { emergency profile }\end{array}$} & Present & 104(53.6) & $6(3.09)$ & $0.000 \neq$ \\
\hline & Absence & $90(46.39)$ & 188(96.9) & \\
\hline \multirow[t]{2}{*}{ Secondary correction } & Need & NA & NA & NA \\
\hline & No need & NA & NA & \\
\hline \multirow[t]{2}{*}{ Time for impression taking } & Ideal or satisfactory soft tissue projection & $112(57.73)$ & 187(96.39) & $0.000 \neq$ \\
\hline & Inadequate projection of the soft tissue & $82(42.26)$ & $7(3.60)$ & $0.000 \neq$ \\
\hline
\end{tabular}

Table 4. Postoperative assessment at 3 weeks in both groups $\left({ }^{*} p<0.05 ;+p<0.01 ; \neq p<0.001 ;\right.$ SD: standard deviation).

\begin{tabular}{|c|c|c|c|c|}
\hline Criteria & Index & Scalpel group & Laser group & $\mathbf{p}$ \\
\hline \multirow[t]{3}{*}{ Mucosal thicknesses (mm) } & Mesial mucosa & $1.55 \pm 0.67$ & $1.70 \pm 0.41$ & $0.000 \neq$ \\
\hline & Mid mucosa & $1.19 \pm 0.62$ & $1.18 \pm .61$ & $0.001 \dagger$ \\
\hline & Distal mucosa & $1.42 \pm 0.90$ & $1.63 \pm 0.55$ & $0.007 \dagger$ \\
\hline \multirow[t]{7}{*}{ Bleeding } & Visual bleeding & $00(00)$ & $00(00)$ & NA \\
\hline & Bleeding on probing & & & \\
\hline & Grade 0 & $118(60.82)$ & $194(100)$ & $0.000 \neq$ \\
\hline & Grade 1 & $59(30.41)$ & $00(00)$ & $0.000 \neq$ \\
\hline & Grade 2 & $9(4.63)$ & $00(00)$ & $0.000 \neq$ \\
\hline & Grade 3 & 6(3.09) & $00(00)$ & $0.000 \neq$ \\
\hline & Grade 4 & $02(1.03)$ & $00(00)$ & $0.000 \neq$ \\
\hline \multirow{4}{*}{$\begin{array}{l}\text { Gingival color } \\
\text { Modified Gingival index }\end{array}$} & Grade 0 & $115(59.27)$ & $186(95.87)$ & $0.001+$ \\
\hline & Grade 1 & 19(9.79) & $8(4.12)$ & $0.001 \dagger$ \\
\hline & Grade 2 & $21(10.82)$ & $00(00)$ & $0.000 \neq$ \\
\hline & Grade 3 & $7(3.60)$ & $00(00)$ & $0.000 \neq$ \\
\hline \multirow{2}{*}{$\begin{array}{l}\text { Soft tissue edema in the gingival } \\
\text { emergency profile }\end{array}$} & Present & $23(11.85)$ & $00(00)$ & $0.000 \neq$ \\
\hline & Absence & $171(88.14)$ & $194(100)$ & \\
\hline \multirow[t]{2}{*}{ Secondary correction } & Need & $23(11.85)$ & $00(00)$ & $0.000 \neq$ \\
\hline & No need & $171(88.14)$ & 194(100) & \\
\hline \multirow[t]{2}{*}{ Time for impression taking } & Ideal or satisfactory soft tissue projection & $148(76.28)$ & 194(100) & $0.005+$ \\
\hline & Inadequate projection of the soft tissue & $46(23.81)$ & $00(00)$ & $0.000 \neq$ \\
\hline
\end{tabular}


at 1, 2, and 3 weeks in gingival color and the presence or absence of soft tissue edema in the gingival emergency profile between laser and control groups. There was marked edema and secondary correction procedure was required (at the postoperative week 3 only) in the control group. A highly statistically significant difference $(p<0.001)$ was observed between the two groups for the criteria of the ideal or satisfactory soft tissue projection in the gingival emergency profile which give the great possibility of the impressions taken immediately or in 1 st week after the laser surgery. (Tables 2, 3 and 4).

\section{Discussion}

There is a very limited amount of literature on the effect of diode laser on preservation of keratinized mucosa around dental implants. The purpose of this clinical trial was to determine if the use of a $940 \mathrm{~nm}$ diode laser improves keratinized mucosal thickness quality and patient comfort compared to routine surgical method by the scalpel.

Our hypothesis stated that patient comfort would improve with $940 \mathrm{~nm}$ diode laser. The aims of the study were to compare intra and postoperative pain, bleeding, and keratinized mucosal thickness quality and quantity between the study and control groups. The results of this study confirmed our hypothesis.

We previously published data on the effectiveness of a 940 $\mathrm{nm}$ Diode Laser during second-stage dental implant surgery (24). The current study involved a larger group of patients with a different parameter of evaluation in the same center. Our data are very interesting in that this null hypothesis was proven when we looked at the data per site of the dental implant and side of the study group. The study group showed that there were statistically significant decreases in the incidence and severity of intra- and post-operative pain and bleeding, improved quality and quantity of keratinized mucosa, and reduced duration of prosthetic treatment after uncovering the dental implant.

Theoretically, the increase in thermal energy caused by the laser beam can spread from the point of impact to the surrounding areas and this may cause postoperative edema and pain $(2,3)$. However, other studies indicated that the diode laser activity on the implant surface neither damages structure nor excessively increases temperature (25)

Matys and Dominiak (26) confirmed that laser ablation permits removal of the soft tissue one layer at a time and allows the emergence profile to be modeled similarly, as in the case of healing screws. These observations are in line with our findings, such that the diode laser resulted in good keratinized mucosal quality and quantity and reduced tissue contraction which allowed for precise modeling of the gum line, easy correction of gingival hypertrophy, and accurate uncovering of the implant by $940 \mathrm{~nm}$ diode Laser ablation. Furthermore, the laser provided uniform ablation, prevented scarring, and caused minimal post-surgical complication, all of which ensured faster wound healing (27).

It should be noted that Kissa et al., (28) reported a controversy regarding the association between an adequate amount of keratinized tissue and the peri-implant health following laser treatment. However, our current study using $940 \mathrm{~nm}$ diode laser ablation increase the amount of keratinized tissue around the dental implants and reduced gingival inflammation.

In accordance with previous studies $(25,26,29)$, the present study also reported an insignificant difference with regards to duration of surgical procedure postoperative pain, healing time, and implant success with the laser diode compared to the scalpel. However, the laser diode resulted in good pain tolerance with only a topical anesthetic during the surgery, as shown by the VAS tests and decreased fear of pain, the latter of which is a primary reason some patients avoid visits to dental surgery facilities.

All the above reduce the duration of prosthetic treatment after the implantation depending on that the fact that the success of both dental implant and prosthetic treatment is depends on establishing a stable soft-tissue barrier to protect the underlying osseous structures and to guarantee a periimplant gingival aesthetics over time (30).

The present study demonstrates the $940 \mathrm{~nm}$ diode laser is advantageous over traditional scalpel use during prosthetic phase of implant surgeries. The quality of the impression was accurate enough in all of cases to prepare a prosthetic reconstruction much earlier than the control group, thus reducing treatment time.

The main limitations of this study, aside that double blinding was not possible, are the limited sample, which may result in restricted power, and the fact that the postoperative clinical assessment was single-blinded. To obtain more meaningful results, future randomized studies should use different detailed radiographical and histological evaluation methods to add more valuable findings and analyze all variables that can influence uncovering dental implants using $940 \mathrm{~nm}$ diode laser and conventional scalpel technique.

\section{Conclusion}

This study suggests that a $940 \mathrm{~nm}$ diode laser is a desirable surgical option to reduce complications (pain and bleeding) when uncovering dental implants. This technique can be utilized for preparing an accurate implant emergence profile, as the laser provides an effective approach for preserving the keratinized mucosa around the implants.

Türkçe Öz: Ikinci Aşama Cerrahisinde Diode laser kullanılarak Implant çevresindeki Keratinize Yumuşak Dokunun Korunması. Amaç: Bu çalışmanın amacı, hasta şikayetinin ve postoperatif olumsuzlukların azaltılmasında, peri-implant keratinize mukozanın korunmasında ve implantlar açıldıktan sonra ölçü kalitesinin artırılmasında, 940nm diode laser ve geleneksel bistüri kullanımının karşılaştırmalı olarak incelenmesidir. Gereç ve Yöntem: Bu çalışmada dental implantlarının üzeri açılması gereken hastalarda ileriye dönük, split-mouth, tek kör, randomize kontrollü klinik araştırma planlanmıştır. Araştırmamıza 73 hastada 388 implant dahil edilmiştir. Split-mouth çalışma yöntemi ağzın bir tarafında laser ile diğer tarafında geleneksel bistüri kullanılarak implantların üzeri açılmıştır. Hastalar cerrahi işlem sırasında ve sonrasında ağrı ve kanama açısından değerlendirilmiştir.Cerrahi işlemden 1,2 ve 3 hafta sora hastalar post-operatif şikayetler, keratinize mukoza kalınlığı kalitesi ve miktarı ve implant çıkış profili kesinliği konularında değerlendirilmiştir. Bulgular: Laser grubunda kontrol grubuna göre istatistiksel olarak anlamlı düzeyde daha fazla kanama ve ağrı az görülmüştür. Ayrıca gruplar arasında 1., 2. Ve 3. Haftalarda anlamlı düzeyde mukoza rengi, yumuşak doku ödemi olup olmaması ve çıkış profilinde fark vardı. Implant çıkıs profilinde iki grup arasında istatistiksel olarak anlamlı $(p<0.001)$ fark vardı. Bu da laser ile işlem yapıldıktan 1 hafta sonra ölçü alınabileceğini gösteriyordu. Sonuç: Dental implantların üzerinin $940 \pm 10 \mathrm{~nm}$ 
dalgaboyu ve 0.4-10W gücünde çalışan diode laser ile açılması implant çıkış profili kesinliği için tavsiye edilebilir. Laser tedavisi ayrıca geleneksel bistüri kullanımına göre keratinize yumuşak dokuyu korumakta etkilidir. Anahtar Kelimeler: Dental implantlar; Diode laser; Çıkış profili; Büstirü yaklaşımı; Keratinize dişeti

Ethics Committee Approval: The study protocol was approved by the Laser Institute Committee.

Informed Consent: The informed consents were provided by the participants.

Peer-review: Externally peer-reviewed.

Author contributions: RA designed the study, generated and gathered the data, wrote and approved the final version of the study.

Conflict of Interest: The author had no conflict of interest to declare.

Financial Disclosure: The author declared that this study has received no financial support.

\section{References}

1. Gellrich N, Rahlf B , Zimmerer R, Pott Ph and Rana MA new concept for implant-borne dental rehabilitation; how to overcome the biological weak-spot of conventional dental implants? Head \& Face Medicine 2017;13:17. [CrossRef]

2. Fornaini $C$, Merigo E, Vescovi P, Bonanini M , Antonietti W, Leoci L, Lagori G \& Meleti M. Different laser wavelengths comparison in the second-stage implant surgery: an ex vivo study. Lasers Med Sci 2015;30:1631-9. [CrossRef]

3. Matys J, Flieger R, Dominiak M. Effect of diode lasers with wavelength of 445 and $980 \mathrm{~nm}$ on a temperature rise when uncovering implants for second stage surgery: An ex-vivo study in pigs. Adv Clin Exp Med 2017;26(4):687-3. [CrossRef]

4. Bednarz W. The thickness of periodontal soft tissue ultrasonic examination - current possibilities and perspectives. Dent Med Probl 2011;48(3):303-10.

5. Hoelscher DC, Simons AM. The rationale for soft-tissue grafting and vestibuloplasty in association with endosseous implants: A literature review. J Oral Implantol 1994;20:282-91.

6. Kan JYK, Rungcharassaeng K, Lozada JL, Zimmerman G. Facial gingival tissue stability following immediate placement and provisionalization of maxillary anterior single implants: A 2- to 8-year follow-up. Int J Oral and Max Impl 2011;26:179-87.

7. Hsu YT, Shieh $\mathrm{CH}$, Wang HL. Using soft tissue graft to prevent mid-facial mucosal recession following immediate implant placement. J Int Acad Periodontol 2012;14:76-82.

8. Cosyn J, Hooghe N, de Bruyn H. A systematic review on the frequency of advanced recession following single immediate implant treatment. J Clin Periodontol 2012;39:582-9. [CrossRef]

9. Bornstein E. Combining multiple technologies to perform minimally invasive laser-assisted dental implant surgery. Dent Today 2003;22(6):52-5.

10. Yeh S, Jain K, Andreana S. Using a diode laser to uncover dental implants in second-stage surgery. J Dent 2005;53:414-7.

11. Arnabat-Domínguez J, España-Tost AJ, Berini-Aytes L, Gay EC. Erbium: YAG laser application in the second phase of implant surgery: a pilot study of 20 patients. Int J Oral Maxillofac Implants 2003;18(1):104-12.

12. Dörtbudak $O$, Haas R, Mallath-Pokorny G. Biostimulation of bone marrow cells with a diode soft laser. Clin Oral Implants Res 2000;11(6):540-5. [CrossRef]
13. Schwarz F, Aoki A, Sculean A, Becker J. The impact of laser application on periodontal and peri-implant wound healing. Periodontol 2009;51:79-108. [CrossRef]

14. Usumez A, Cengiz B, Oztuzcu S, Demir T, Aras MH, Gutknecht $\mathrm{N}$. Effects of laser irradiation at different wavelengths $(660,810$, 980 , and 1,064 nm) on mucositis in an animal model of wound healing. Lasers Med Sci 2014;29(6):1807-13. [CrossRef]

15. Elanchezhiyan S, Renukadevi R, Vennila K. Comparison of diode laser-assisted surgery and conventional surgery in the management of hereditary ankyloglossia in siblings: A case report with scientific review. Lasers Med Sci 2013;28(1):7-12. [CrossRef]

16. Sagar K, Kaur A, Patel P, Kumar V, Narang S, Ranga P. Diode laser as an established tool in periodontics - a review. American Journal of Oral Medicine and Radiology 2015;2:54-60.

17. Aoki A, Mizutani K, Schwarz F, et al. Periodontal and periimplant wound healing following laser therapy. Periodontol 2000 2015;68(1):217-69. [CrossRef]

18. Matys J, Botzenhart U, Gedrange T, Dominiak M. Thermodynamic effects after Diode and Er:YAG laser irradiation of grade IV and V titanium implants placed in bone - an ex vivo study. Preliminary report. Biomed Eng 2016;5:499-507. [CrossRef]

19. Heinemann F, Hasan I, Kunert-Keil C, et al. Experimental and histological investigations of the bone using two different oscillating osteotomy techniques compared with conventional rotary osteotomy. Ann Anat 2012;194(2):165-70. [CrossRef]

20. Eriksson AR, Albrektsson T. Temperature threshold levels for heatinduced bone tissue injury: A vital-microscopic study in the rabbit. J Prosthet Dent 1983;50(1):101-7. [CrossRef]

21. Eriksson AR, Albrektsson T, Magnusson B. Assessment of bone viability after heat trauma. A histological, histochmeical and vital microscopic study in the rabbit. Scand J Plast Reconstr Surg Hand Surg 1984;18(3):261-8. [CrossRef]

22. Lekholm U, Zarb GA. Patient selection and preparation. Branemark PI, Zarb GA, Albrektsson T, editors., eds. Tissueintegrated prostheses; osseointegration in clinical dentistry. Chicago: Quintessence; 1985.

23. Webert KE, Cook RJ, Sigouin CS, et al. The risk of bleeding in thrombocytopaenic patients with acute myeloid leukaemia. Haematologica 2006;91:1530-7.

24. Al-Delayme RMA, Awazli LG. Evaluation of the effectiveness of $940 \mathrm{~nm}$ Diode Laser in second-stage Dental Implant Surgery compared with the Conventional Scalpel Procedure: An in vivo Study. Int J Oral Craniofac Sci 2017;3(2):039-045. [CrossRef]

25. El-Kholey KE. Efficacy and safety of a diode laser in secondstage implant surgery: a comparative study. Int J Oral Maxillofac Surg 2013; 6. pi:S0901-5027 (13) 01113-2.

26. Matys J, Dominiak M. Assessment of Pain When Uncovering Implants with Er: YAG Laser or Scalpel for Second Stage Surgery Adv Clin Exp Med 2016;25(6):1179-84. [CrossRef]

27. Gabrić Pandurić $D$, Sušić $M$, Brozović J, Smojver I, Vučićević V, Katanec D: Diode and Er: YAG laser vs. conventional technique for second stage surgery. Clin Oral Impl Res 2014;25:397.

28. Kissa J, El Kholti W, Laalou Y, El Farouki M. Augmentation of keratinized gingiva around dental implants J Stomatol Oral Maxillofac Surg 2017;118:156-60. [CrossRef]

29. Fornaini C, Merigo E, Vescovi P, Bonanini M, Antonietti W, Leoci $L$, Lagori G, Meleti M. Different laser wavelengths comparison in the second-stage implant surgery: an ex vivo study Lasers Med Sci 2015;30:1631-9. [CrossRef]

30. Andeson M, Andrisan C, Lico S, Silvestre F, Gargari M, Arcuri C. Increasing volume of vestibular soft tissues in flapless implant surgery through a modified connective punch technique: a controlled clinical trial Oral \& Implantology - anno IX - n. 3/2016. 